\title{
Interaction between southern sea lions Otaria flavescens and jack mackerel Trachurus symmetricus commercial fishery off Central Chile: a geostatistical approach
}

\author{
Luis A. Hückstädt*, M. Cristina Krautz \\ Departamento de Oceanografía, Universidad de Concepción, Casilla 160-C, Concepción, Chile
}

\begin{abstract}
A spatial description of the operational interaction between southern sea lions and jack mackerel fishing fleet off Central Chile is presented. The descriptive analysis showed a similar spatial trend for the number of sea lions per haul and catch per haul, both increasing in the SE direction, and decreasing in the NW direction. The number of sea lions was positively correlated with catches at intermediate distances from land, while negatively correlated with the number of fishing vessels at the greatest distance from the land. The geostatistical analyses corroborate the trends found during the descriptive analysis: 2 nuclei of high abundance of sea lions were found, which spatially overlapped 2 nuclei of high jack mackerel catches; nuclei that we proposed here as hot-spots for this interaction. Both hot-spots were located on the continental slope and over the deep ocean bed. No spatial relation was found between the number of sea lions and the number of fishing vessels. Thus, it is proposed that the area enclosed between $38-40^{\circ} \mathrm{S}$ and $74-75^{\circ} 30^{\prime} \mathrm{W}$ constitutes the sector of higher interaction between the southern sea lions and jack mackerel industrial fishing fleet.
\end{abstract}

KEY WORDS: Otaria flavescens - Trachurus symmetricus - Commercial fishery - Interaction · Geostatistics · Central Chile

\section{INTRODUCTION}

Coastal otariids are considered as generalist predators, located at high levels in trophic webs (FAO 1977, Beverton 1985), and participants in several interactions that involve the fishing sector (Wickens 1995). These interactions can be understood, in a broad sense, to be due to the concentration of fishing activities in coastal ecosystems, where fishing grounds overlap with otariids' feeding grounds, resulting in conflicts during the fishing operations and/or the occurrence of potential conflicts derived from changes in the common resources/prey (Shima et al. 2000), e.g. the removal of resources that constitute prey for the marine mammals (Jennings \& Kaiser 1998).

The southern sea lion Otaria flavescens occurs along the entire Chilean coast. According to the most recent estimates on population size, about 100000 individuals inhabit Chilean waters (Sielfeld et al. 1997, AguayoLobo et al. 1998, Oporto et al. 1999). Off Central Chile, the 3 most important prey items in the diet of sea lion are the whiptail hake Macruronus magellanicus, the cusk eels Genypterus spp. and the jack mackerel Trachurus symmetricus (George-Nascimento et al. 1985).

Pinnipeds may interact with fisheries during fishing operations (operational interaction), besides the biological interaction that results from sharing the same prey. The operational interaction results in various outcomes for both the pinnipeds and the fishery, mostly causing negative impacts upon one or both parties (e.g. Shaughnessy 1985, Wickens et al. 1992, Wickens 1995, Bjørge et al. 2002), while in some rare cases, interactions may provide clear advantages to pinnipeds. 
Several authors have previously reported on the development of interactions between southern sea lion Otaria flavescens, and artisanal fisheries and fish farms (e.g. Aguayo \& Maturana 1973, Torres 1979, Sielfeld et al. 1997, Aguayo-Lobo et al. 1998, Sepúlveda 1998). Southern sea lions have been reported to interact with the industrial purse-seiner's fleet of jack mackerel off Central Chile (Hückstädt \& Antezana 2003). This interaction has been described as a modification of sea lions in order to benefit from being able to feed in close association with the fleet as a result of the herding effect of purse-seining. In addition, negative consequences of this interaction were considered lower than expected for both participants, with an operational consumption of $0.4 \%$ of the vessels' catches and an incidental mortality rate of 0.03 ind. haul ${ }^{-1}$.

Although otaria flavescens has been historically considered as coastal for Chilean waters (Vaz-Ferreira 1979, Rivera 1990), recent studies have expanded its range to over $300 \mathrm{~km}$ from the coast for males and 250 $\mathrm{km}$ for females (Campagna et al. 2001).

Along the Chilean coast, jack mackerel is constituted as 1 stock unit, although it is distributed heterogeneously (Grechina 1998). The largest biomass is concentrated off Central Chile, between 32 and $40^{\circ} \mathrm{S}$ (SUBPESCA 2000), which supports elevated exploitation levels compared to other fishing grounds (north and south). On the other hand, $17 \%$ of the sea lion population is also concentrated in this area (Aguayo-Lobo et al. 1998).

Geostatiscal analyses allow the description of the correlation, or spatial continuity, of 1 variable by modelling its variability (Isaaks \& Srivistava 1989), and hence, making it possible to estimate values for that variable at any determined point (Petitgas 2001). Geostatistics rely on spatial models, which assume that the variables under study are random, as well as the actuality in the field being the outcome of one or more random processes, and that the models on which predictions are based are those of random processes (Webster \& Oliver 2001). These features allow the data to be analysed without considering the restrictions of the sampling design.

Thus, a geostatistical approach constitutes a robust tool to estimate the spatial distribution of marine populations (Petitgas 1993, Rueda 2001). For Chilean waters, geostatistical tools have been used for spatial modelling and mapping of some important fishing resources like the anchoveta Engraulis ringens (Castro et al. 1996, Oliva et al. 2001, 2002, Cubillos et al. 2003), as well as for estimating the biomass of the squat lobster Pleuroncodes monodon (Roa \& Tapia 2000). Nevertheless, there are no antecedents for the area on using geostatistical approaches with marine mammals.

Thus, this work is intended to spatially characterise the operational interaction between southern sea lions and the jack mackerel fishing fleet by means of geostatistical analysis, using data collected directly from fishing operations of purse-seiners off Central-South Chile during 2002.

\section{MATERIALS AND METHODS}

The data were obtained directly from the operations of Central Chile's purse-seiner fleet. On board, observers collected data from April to September 2002, months with the greatest numbers of landings of jack mackerel between 1990 and 1997 (SUBPESCA 2000). Information from 82 fishing hauls, conducted by 4 vessels, was included and analysed in this study. These vessels are considered as average vessels for the jack mackerel purse-seiner's fleet in Central Chile, with lengths ranging between 46 and $66 \mathrm{~m}$, widths between 10 and $12 \mathrm{~m}$, and storage capacities between 1000 and $1440 \mathrm{~m}^{3}$.

The data consisted of the following variables: (1) number of sea lions per fishing haul, based on censuses of sea lions observed at the sea surface, around and inside the purse-seine net, using 10 to $30 \times 30$ binoculars during the last phases of the haul (net retrieval and transfer of the catch on board), when the maximum number of sea lions around purse-seiners is recorded (Hückstädt \& Antezana 2003); (2) total catch per haul; and (3) number of purse-seiners within $12 \mathrm{n}$ mile of the fishing vessel. This area was considered to be the distance that a sea lion could cover over the duration of a fishing haul (ca. $2 \mathrm{~h}$ ) swimming at top speed, according to the velocities established for the species by Campagna et al. (2001).

Observations conducted by non-specialists, with more sea lions per haul than the maximum number reported by Hückstädt \& Antezana (2003), were not considered in the analyses. Thus, 79 out of 82 fishing hauls were considered in this study (Fig. 1a).

Descriptive analysis. The descriptive spatial exploration was carried out based on the moving windows statistics approach (Isaaks \& Srivistava 1989). By estimating the mean and standard deviation (SD) for the variables under study inside the moving windows, it is possible to assess the existence of anomalies both among the mean values, as well as anomalies of the variability of such values or heteroscedasticity (Isaaks \& Srivistava 1989). The moving windows allow univariate analysis in small portions of a certain phenomenon, which is spatially modulated. In addition, this tool let us establish the occurrence of proportional effect among the data (understood as the linear relationship between mean and SD for each moving window), which would imply a violation of the second order stationarity assumption (Isaaks \& Srivistava 1989). 
The sampling area $\left(36^{\circ} 30^{\prime}\right.$ to $40^{\circ} 30^{\prime} \mathrm{S}$ and $73^{\circ} 30^{\prime}$ to $\left.76^{\circ} 30^{\prime} \mathrm{W}\right)$ was partitioned into 11 square windows, each of an area of $2 \times 2^{\circ}$, and overlapping by $1^{\circ}$ with the neighbouring windows. The latter was done in order to consider a minimal number of observations for each window that would allow us to obtain reliable statistics and the necessary detail for the analyses (Fig. 1b).

In each established moving window, mean and SD were computed for the variables: number of sea lions per haul, catch per haul (ton) and number of purseseiners. The existence of linear correlations among the variables was also approached ( $p=0.05)$, as well as the presence of the proportional effect, which allows one to establish if changes in local variability are related or not, with local means (Isaaks \& Srivistava 1989).

Geostatiscal analysis. Firstly, the variables under study (number of sea lions, catch and number of purseseiners) were normalised through logarithmic transformation of the observations, $\log _{10}(x+1)$, and later structurally analised using the variogram method which enables statistical modelling of the average degree of similarity between values of variable $x$, as a function of the distance (Rossi et al. 1992). Hence, the variables were analysed using the experimental variogram, $\gamma^{*}(h, \theta)$, defined as:

$$
\gamma^{*}(h, \theta)=\frac{\sum_{i=1}^{N(h)}\left[z\left(x_{i}\right)-z\left(x_{i}+h\right)^{2}\right]}{2 N(h)}
$$

where $z\left(x_{i}\right)$ is the value for the variable at point $x_{i}, z\left(x_{i}\right.$ $+h$ ) is the value for the variable at a given location separated from $x_{i}$ by a discrete distance $h(\mathrm{~km})$ and $N(h)$ is the number of pairs of observations separated by a distance $h$.

The presence of anisotropy among our observations, i.e. differences in the continuity range in different directions (Isaaks \& Srivistava 1989), was approached as well and when confirmed, the axis of major continuity or azimuth, the anisotropy ratio (defined as the ratio between the range for the azimuth direction and the range for the direction perpendicular to the azimuth direction), and type of anisotropy (i.e. geometric and/or zonal) were determined. Therefore, anisotropy involves the orientation of the phenomenon under study due to spatial constraints of the area where it occurs. Particularly, at the Chilean coast, the distribution of marine populations and associated processes is commonly modulated by the coastal configuration. The second part of the geostatistical analysis consisted of modelling, or estimating, the theoretical variogram. Thus, the experimental variogram of any isotropic variable is adjusted to a determined model by minimising the weighted minimal square sum (WMSS) by the number of pairs for each distance category or lag
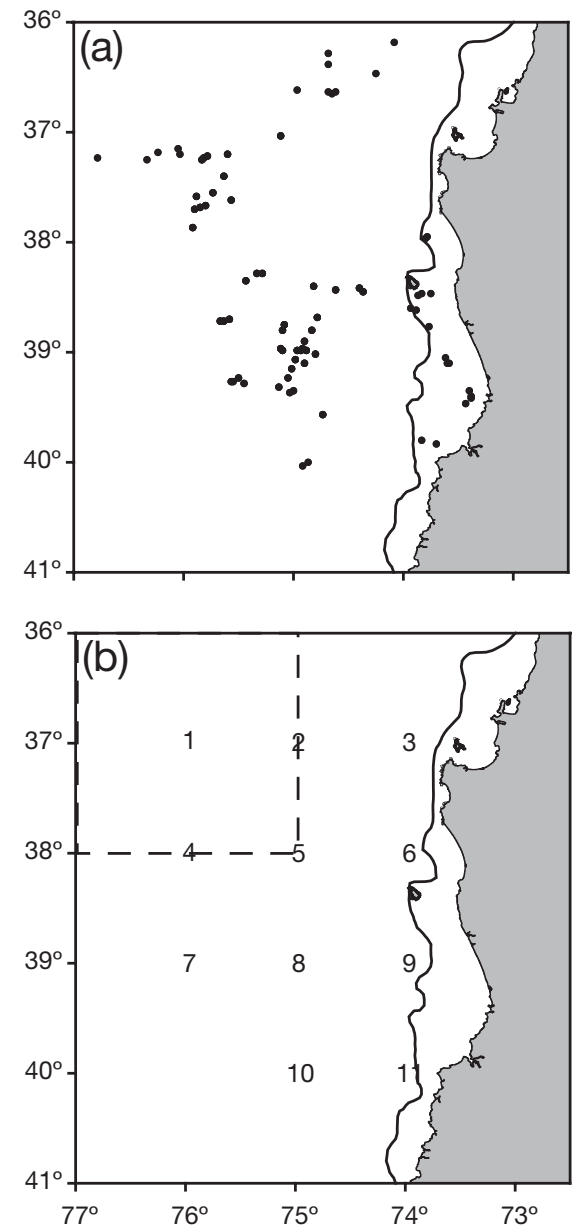

Fig. 1. Map of the study area showing (a) spatial distribution of sampled fishing hauls along Central Chile $(\mathrm{n}=79)$ and $(\mathrm{b})$ distribution and coverage surface of moving windows $\left(2 \times 2^{\circ}\right)$ utilized in the descriptive analysis (Latitude ${ }^{\circ} \mathrm{S}$, Longitude $\left.{ }^{\circ} \mathrm{W}\right)$. The figure shows the $200 \mathrm{~m}$ depth isoline

(Cressie 1993). A large number of pairs per lag allows the estimation of a more robust variogram.

Since in this study the 3 variables presented both types of anisotropy, the system of coordinates should be transformed according to the method proposed by Goovaerts (1997), resulting in an anisotropic model $g_{2}(h)$, expressed as a spherical isotropic model $g_{2}^{t}=$ $\left(\left|h^{\prime}\right|\right)$, with range $a_{\phi}$ :

$$
g_{2}(h)=g_{2}^{t}\left(\left|h^{\prime}\right|\right)=\operatorname{Sph}\left(\frac{\left|h^{\prime}\right|}{a_{\phi}}\right)
$$

The spherical model is defined as:

$$
\gamma^{*}(h, \theta)=\left\{\begin{array}{cc}
0, & h=0 \\
c_{0}+C\left[\frac{3}{2}\left(\frac{\|h\|}{\beta}\right)\right]-\frac{1}{2}\left(\frac{\|h\|}{\beta}\right)^{3}, & 0<\|h\|<\beta \\
C_{0}+c_{1} & \|h\| \geq \beta
\end{array}\right.
$$


Table 1. Descriptive spatial analysis based on the moving windows statistics approach. The table indicates the corresponding spatial range, number of fishing hauls sampled (n) and basic statistics for the variables under study

\begin{tabular}{|c|c|c|c|c|c|c|c|c|c|}
\hline \multirow{2}{*}{$\begin{array}{l}\text { Moving } \\
\text { window }\end{array}$} & \multicolumn{2}{|c|}{ Location } & \multirow[t]{2}{*}{$\mathrm{n}$} & \multicolumn{2}{|c|}{ No. sea lions } & \multicolumn{2}{|c|}{ Catch (ton) } & \multicolumn{2}{|c|}{ No. purse-seiners } \\
\hline & Latitude $\left({ }^{\circ} \mathrm{S}\right)$ & Longitude $\left({ }^{\circ} \mathrm{W}\right)$ & & Mean & $\mathrm{SD}$ & Mean & SD & Mean & $\mathrm{SD}$ \\
\hline 1 & $36-38$ & $75-77$ & 18 & 2.11 & 3.32 & 72.22 & 31.35 & 10.5 & 4.15 \\
\hline 2 & $36-38$ & $74-76$ & 21 & 8 & 9.26 & 125.24 & 131.59 & 9 & 4.98 \\
\hline 3 & $36-38$ & $73-75$ & 10 & 15.1 & 9.39 & 254 & 212.61 & 4.6 & 3.24 \\
\hline 4 & $37-39$ & $75-77$ & 28 & 8.29 & 10.38 & 137.86 & 124.99 & 3.89 & 2 \\
\hline 5 & $37-39$ & $74-76$ & 34 & 13.83 & 15.86 & 190 & 145.26 & 8.47 & 5.34 \\
\hline 6 & $37-39$ & $73-75$ & 19 & 16.05 & 17.74 & 285 & 154.43 & 9.96 & 5.08 \\
\hline 7 & $38-40$ & $73-75$ & 30 & 15 & 8.88 & 215.26 & 121.26 & 8.74 & 4.92 \\
\hline 8 & $38-40$ & $74-76$ & 34 & 16.49 & 14.5 & 235.57 & 140.65 & 7.56 & 4.80 \\
\hline 9 & $38-40$ & $75-77$ & 19 & 14.74 & 15.07 & 221.13 & 143.36 & 5.57 & 4.16 \\
\hline 10 & $39-41$ & $74-76$ & 15 & 10.53 & 5.26 & 201.67 & 118.59 & 7.67 & 4.92 \\
\hline 11 & $39-41$ & $73-75$ & 15 & 12.27 & 7.60 & 193 & 138.69 & 8.87 & 3.6 \\
\hline
\end{tabular}

The following parameters were estimated: nugget $\left(C_{0}\right)$ or microscale error, sill $\left(C_{0}+C\right)$, which defines the asymptotic value for the variogram $(C)$, and $\beta$ or range, which defines the distance after which there is no correlation between observations (continuity).

The results obtained through the modelling were compared to the original values using the cross validation approach, which allowed one to test whether the variability of the observations is indeed reproduced by the theoretical variogram and the search parameters in the area (Englund \& Sparks 1988). The search parameters were selected by estimating the mean square error (MSE) from the residuals obtained during the cross validation, choosing that parameter's combination with the minimum MSE, implying that both the bias and residuals' dispersion are close to zero.

Once the theoretical variogram and the search parameters were established, the data were spatially interpolated using ordinary point kriging, which enables the estimation of values for the variables, conferring more relative weight to estimations of closer points located inside the influence range (Petitgas 1996). Kriging results enabled bi-dimensional mapping of isolines, and hence allowed the definition of nuclei of high abundance for the number of sea lions, catch and number of purse-seiners in the sampling area.

\section{RESULTS}

\section{Descriptive analysis}

The mean number of sea lions per haul varied among windows, with a minimum of 2.11 sea lions $(\mathrm{SD}=3.32$, Window 1) and a maximum of 16.49 sea lions ( $\mathrm{SD}=$ 14.5, Window 8). Higher mean values were observed in those windows located towards the south and closer to the coastline. In general, standard deviation values showed great variability among the windows (Table 1).

Regarding the catch (Table 1), mean values per window varied between 72.22 (SD $=31.35$, Moving Window 1 ) and 285 ton (SD = 154.43, Moving Window 6). A decreasing trend was observed in the NW direction (Windows 1, 2 and 4), whereas catches around $200 \mathrm{t}$ were observed for the rest of the windows. It was also observed that Moving Window 3 presented the highest variation in catches $(\mathrm{SD}=212.61)$.

The mean number of purse-seiners per window varied between 3.89 (SD = 2, Moving Window 4) and 9.96 ( $\mathrm{SD}=$ 5.08, Moving Window 6). Unlike previous variables, the number of purse-seiners did not denote a notorious internal variation, which impeded determination of the presence of any differentiation among windows, or establishment of any spatial trend (Table 1).

The number of sea lions and catch per haul were positively correlated only for those windows located to the northwest of the study area (Moving Windows 2, 3, 4, 5 and 7), with the only exception of Moving Window 1 , where no relation was found.

There was no relation between the number of sea lions and the number of purse-seiners (Table 2), with the exception of Moving Window 1, where a positive significant relation was found between the variables $\left(r^{2}=0.49\right)$.

Finally, no significant relation was found between number of purse-seiners and catch, for any window (Table 2).

\section{Geostatistical analysis}

Number of sea lions

The omni-directional variogram for this variable resulted in a minimal number of pairs per lag of 158 
and a lag distance of $55.6 \mathrm{~km}$. The azimuth direction $(\theta)$ was $30^{\circ} \mathrm{W}$ and the anisotropy ratio was 3 .

The variable was adjusted to the anisotropic model $g_{2}(h)$, or spherical isotropic model $g_{2}^{t}=\left(\left|h^{\prime}\right|\right)$ (WMSS = 3.49) (Fig. 2). The dependence spatial range for the number of sea lions ( $\beta$ ) was slightly larger than $116 \mathrm{~km}$, with a microscale error $\left(C_{0}\right)$ corresponding to $46 \%$ of the sill (0.22). The kriging interpolation (Fig. 3) shows the presence of 2 nuclei of larger sea lion abundance $(>1.25)$ : a coastal nucleus, located at $72 \mathrm{~km}$ from the closest haul-out $\left(38^{\circ} 30^{\prime} \mathrm{S}, 74^{\circ} 20^{\prime} \mathrm{W}\right)$, and an oceanic nucleus, located at $154 \mathrm{~km}$ from the closest haul-out $\left(38^{\circ} 20^{\prime} \mathrm{S}, 75^{\circ} 20^{\prime} \mathrm{W}\right)$. Likewise, the map shows the existence of a low abundance nucleus at $109 \mathrm{~km}$ from the closest haul-out $\left(38^{\circ} 25^{\prime} \mathrm{S}, 74^{\circ} 48^{\prime} \mathrm{W}\right)$. From the map, a spatial trend is evident with low abundances of sea lions in the NW direction, and larger abundances of sea lions towards the south and, obviously, towards the coast.

\section{Catch}

The experimental variogram for the variable catch (Fig. 5), presented a minimal number of pairs per lag of 98 and a lag distance of $40.7 \mathrm{~km}$. The azimuth direction $(\theta)$ was $26^{\circ} \mathrm{W}$ and the anisotropy ratio was 4.27. The experimental variogram was adjusted to the anisotropic model $g_{2}(h)$ or spherical isotropic model $g_{2}^{t}=\left(\left|h^{\prime}\right|\right)($ WMSS $=5.63)$ (Fig. 4). The results showed a continuity range $(\beta)$ of $33.3 \mathrm{~km}$; the nugget $\left(C_{0}\right)$ was 0 , and the sill was 0.136 . When $C$ was interpolated through kriging (Fig. 5), the presence of several small nuclei with high catches was evident $(C>2.3)$, most of which were located far away from the coastline.

Table 2. Linear correlation coefficients $\left(\mathrm{r}^{2}\right)$ between the variables No. sea lions, catch and No. purse-seiners inside the moving windows. Significant correlations at the $95 \%$ confidence level $\left({ }^{*}\right)$

\begin{tabular}{|lccc|}
\hline $\begin{array}{l}\text { Moving } \\
\text { window }\end{array}$ & $\begin{array}{c}\text { No. sea lions } \\
\text { Catch }\end{array}$ & $\begin{array}{c}\text { No. sea lions } \\
\text { No. purse-seiners }\end{array}$ & $\begin{array}{c}\text { Catch } \\
\text { No. purse-seiners }\end{array}$ \\
\hline 1 & 0.39 & $0.49^{*}$ & 0.36 \\
2 & $0.71^{*}$ & -0.41 & -0.30 \\
3 & 0.52 & -0.08 & -0.28 \\
4 & $0.76^{*}$ & -0.15 & -0.23 \\
5 & $0.45^{*}$ & -0.22 & -0.28 \\
6 & 0.04 & 0.30 & 0.34 \\
7 & $0.57^{*}$ & -0.09 & -0.18 \\
8 & 0.19 & -0.03 & 0.04 \\
9 & 0.03 & -0.08 & 0.09 \\
10 & 0.12 & 0.31 & 0.50 \\
11 & 0.06 & -0.37 & 0.01 \\
\hline
\end{tabular}

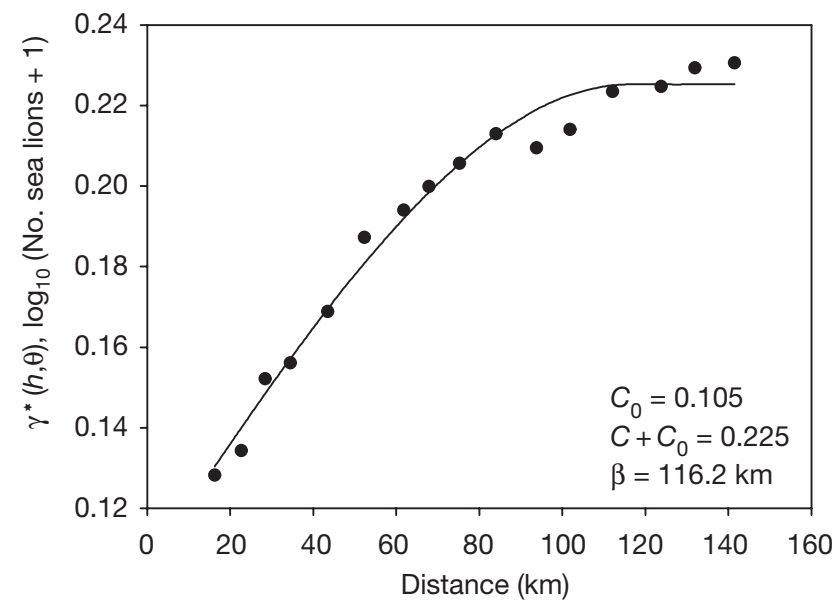

Fig. 2. Omni-directional variogram for variable log (No. sea lions +1$)(\bullet)$, adjusted to the anisotropic model $g_{2}(h)$, or spherical isotropic model $g_{2}^{t}=\left(\left|h^{\prime}\right|\right)$ (weighted minimal square sum [WMSS] $=3.49)(-)$

Furthermore, the map denotes an increasing trend in catches towards the SE quadrant in the study area. On the other hand, towards the northwest, a decreasing trend in catches is evident $(C<2.15)$, as the nucleus with lower catches is consistently found in the NW area $(C<1.0)$.

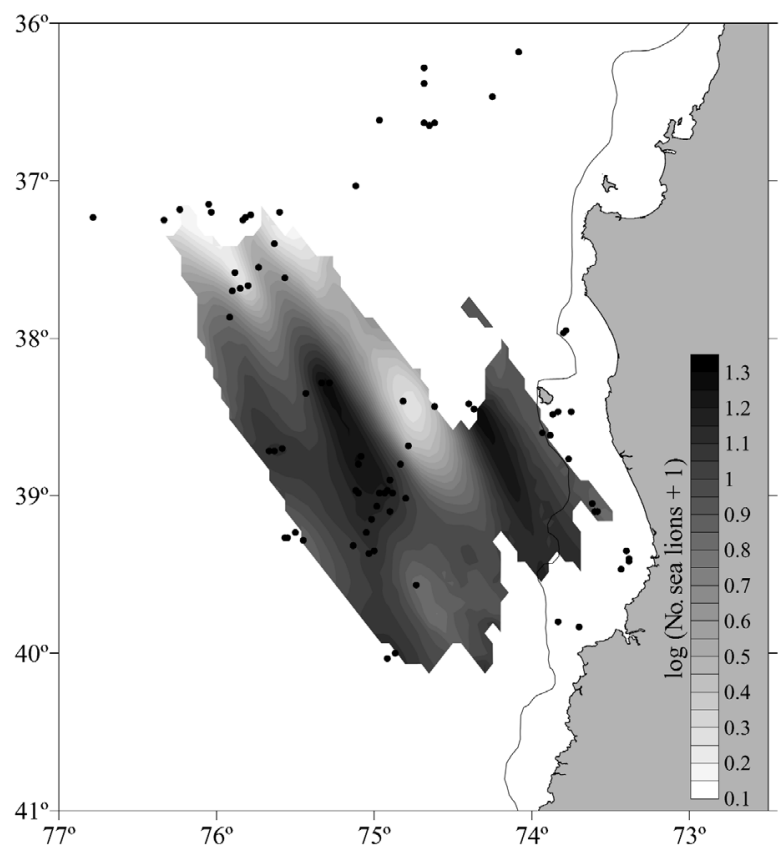

Fig. 3. Spatial interpolation obtained through ordinary point kriging for the number of sea lions, values expressed as log $($ No. sea lions +1$)$. Locations of sampled fishing hauls and the $200 \mathrm{~m}$ depth isoline are also shown 


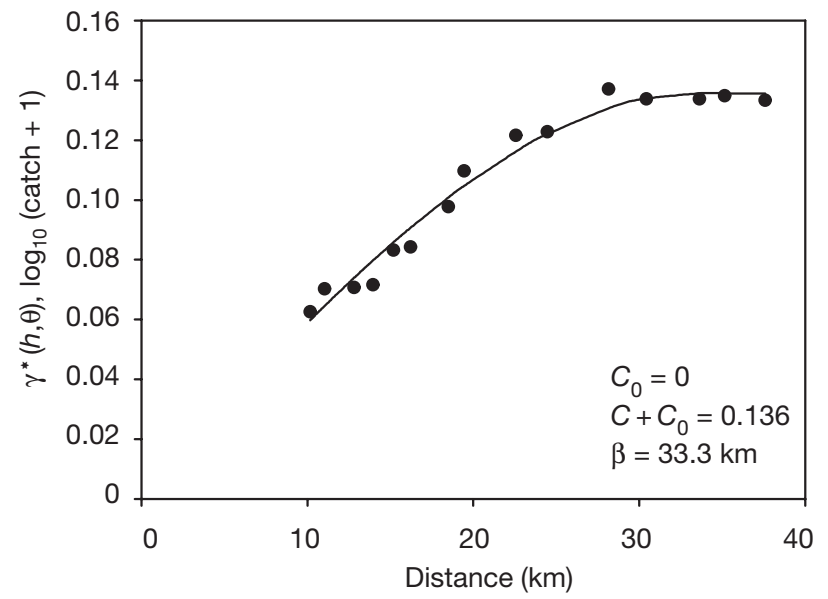

Fig. 4. Omni-directional variogram for variable log $($ catch +1$)$ $(\bullet)$, adjusted to the anisotropic model $g_{2}(h)$, or spherical isotropic model $g_{2}^{t}=\left(\left|h^{\prime}\right|\right)(\mathrm{WMSS}=5.63)(-)$

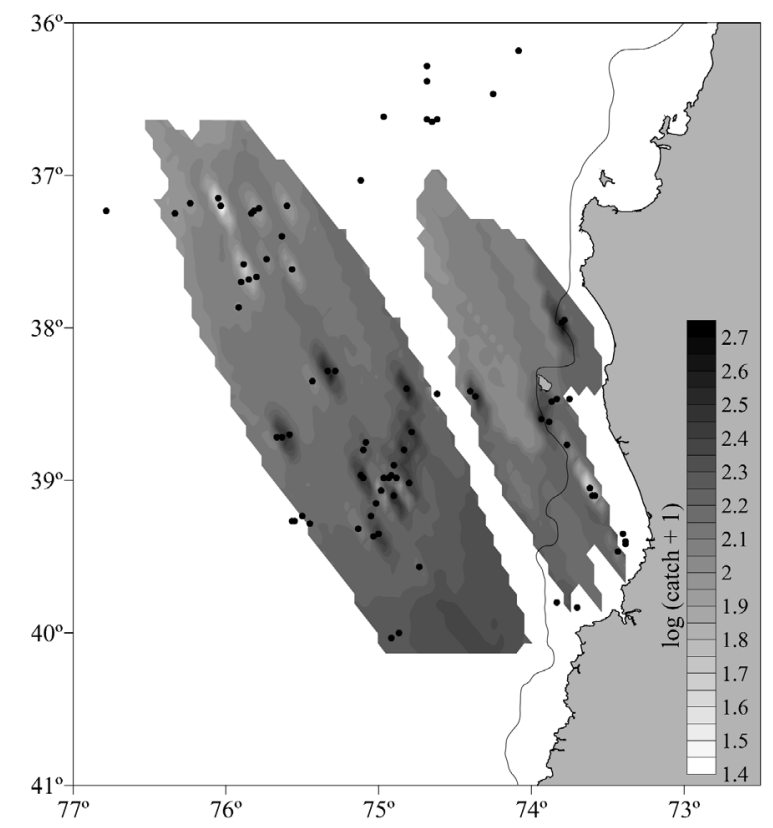

Fig. 5. Spatial interpolation obtained through ordinary point kriging for the catch, values expressed as $\log ($ catch +1$)$. Locations of sampled fishing hauls and the $200 \mathrm{~m}$ depth isoline are also shown

\section{Number of purse-seiners}

The structural analysis for this variable proved the occurrence of a slight anisotropy. The azimuth direction corresponded to $(\theta) 70^{\circ} \mathrm{E}$ and the anisotropy ratio was ca. 1.6. Therefore, the variogram of number of purse-seiners was also adjusted to the anisotropic model $g_{2}(h)$, or spherical isotropic model $g_{2}^{t}=\left(\left|h^{\prime}\right|\right)$ $($ WMSS $=0.73$; Fig. 6$)$. The continuity range $(\beta)$ was

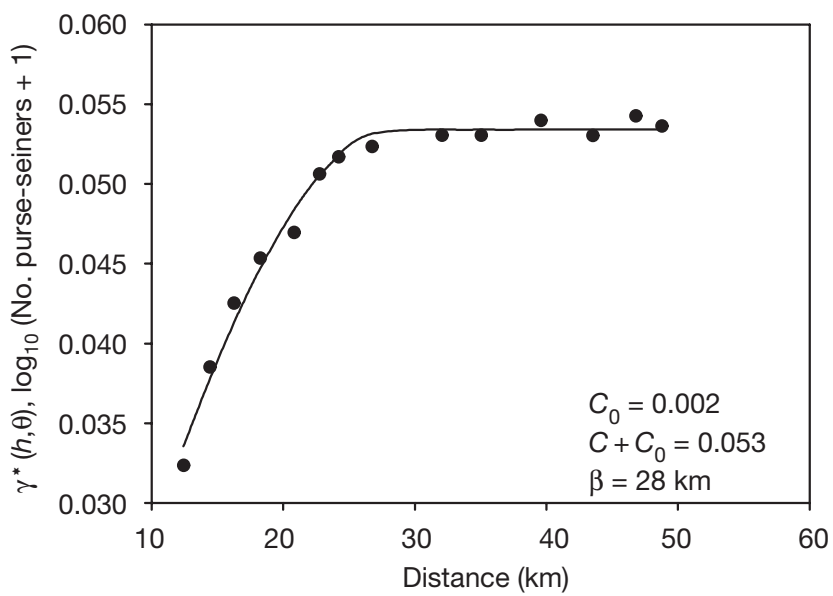

Fig. 6. Omni-directional variogram for variable log (No. purse-seiners +1$)(\bullet)$, adjusted to the anisotropic model $g_{2}(h)$, or spherical isotropic model $g_{2}^{t}=\left(\left|h^{\prime}\right|\right)($ WMSS $=0.73)(-)$

$28 \mathrm{~km}$, the nugget $\left(C_{0}\right)$ was 0.0019 , which represents $3.7 \%$ of the sill $(0.053)$.

From the map obtained through kriging (Fig. 7), there is an obvious absence of areas where the fleet concentrated its operations, with a low variability in the number of purse-seiners throughout the study area. Several minor nuclei with relatively low purseseiner abundances were present (ca. 1.3), as well as some areas where the presence of purse-seiners was rare (ca. 0.35). Thus, the results showed a large homogeneity in the distribution of the fleet for the study area.

\section{DISCUSSION}

The study area is part of the Humboldt Current System (HCS), which flows northward along the coast of Chile and Peru in South America. Along the HCS, the biological productivity is very patchy in space, centered around isolated areas with special topography, like the shelf off Concepcion, Chile, at $36^{\circ} 30^{\prime} \mathrm{S}$ (Sobarzo et al. 2001). During the austral summer (September-March), the mean surface wind in the study area is southerly, favouring the development of upwelling events with the consequent strengthening of biological productivity. This feature implies that this region alone supports between 50 and $90 \%$ of the annual Chilean fish catches (SERNAPESCA 2002).

The jack mackerel's commercial fishery presents a seasonal variability, highly influenced by the behaviour of the species, which migrates outside the Chilean Economical Zone for the reproduction period during mid-spring and summer months (SUBPESCA 2000). Thus, this study covered the period when the fleet is 


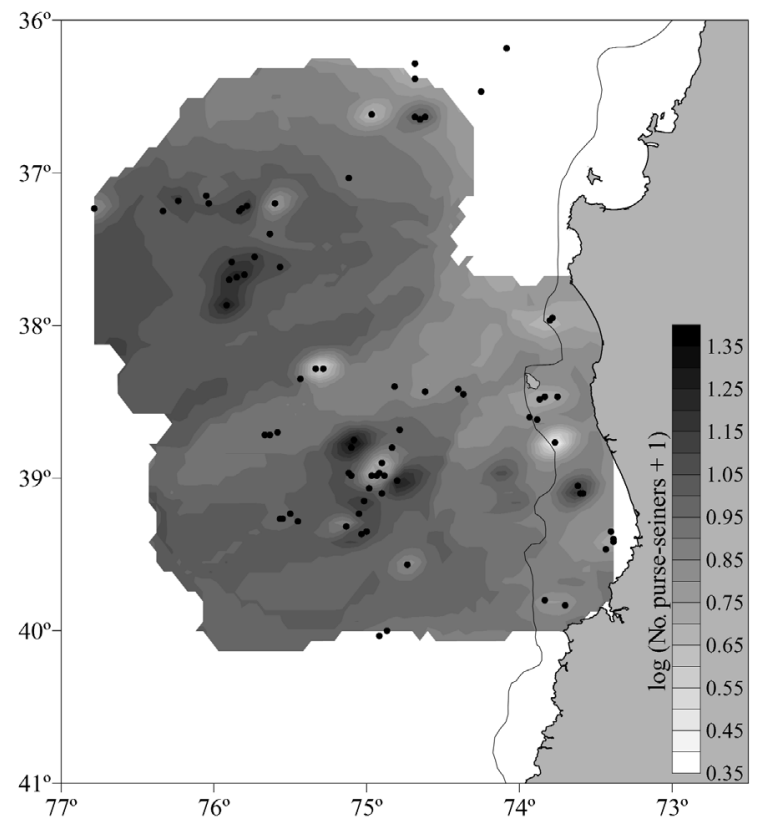

Fig. 7. Spatial interpolation obtained through ordinary point kriging for the number of purse-seiners, values expressed as $\log$ (No. purse-seiners +1 ). Locations of sampled fishing hauls and the $200 \mathrm{~m}$ depth isoline are also shown

actively fishing on this resource in Chilean waters. During the jack mackerel's migration period, the purse-seiner's fleet focuses on non-migratory jack mackerel, as well as alternative resources (e.g. whiptale hake), but monthly catches drop to less than 50000 t (SUBPESCA 2000). Since sea lions interacting with purse-seiner fleets are mainly adults (L. A. Hückstädt \& T. Antezana unpubl. data), it is expected that the interaction will decrease during this period, as coincidentally sea lions enter into their reproductive period and feeding is dramatically reduced.

Several authors have approached the topic of interactions between pinnipeds and fisheries, as well as their causes and consequences, in distinct ecosystems worldwide (Northridge 1984, Wickens 1995). Nonetheless, limited attention has been paid to spatial aspects of such interactions, even though a better understanding of the spatial scales of these relationships would facilitate the implementation of management plans and mitigation of the derived conflicts (Bjørge et al. 2002). In this study, the interaction that occurs between the jack mackerel commercial fishery and southern sea lions (Hückstädt \& Antezana 2003) was approached from a spatial perspective for the first time.

Southern sea lions have been proposed as a coastal species off the Chilean coast (Rivera 1990). However, in Argentinean waters (Argentinean Patagonia and Falkland Islands), diverse research programs have implemented satellite tracking of lactating females and sub-adult males (Werner \& Campagna 1995, Thompson et al. 1998, Campagna et al. 2001), recording the presence of sea lions offshore up to 258 and $307 \mathrm{~km}$ from the closest haul-out for females and males, respectively (Campagna et al. 2001). On the other hand, these authors describe southern sea lions as a species associated with the continental shelf, which can reach $400 \mathrm{~km}$ from the coast in that area. In the present study, sea lions were observed occurring in association with the jack mackerel fishing fleet at distances of up to $300 \mathrm{~km}$ from the closest haul-out point, coinciding with the spatial range described for the species in Argentinean waters. Nevertheless, the Chilean continental shelf is considerably narrower than the Argentinean, with a maximum width of $66 \mathrm{~km}$ in the study area (Sobarzo et al. 2001). It would, therefore, appear that the southern sea lion is not associated with the continental shelf since it can reach waters far away from the continental shelf edge, with depths of about $5000 \mathrm{~m}$. The Northern fur seal Callorhinus ursinus has also been known to reach waters off the continental shelf during post-breeding trips (Loughlin et al. 1999).

The methodological approach used in this work to estimate the abundances of sea lions around purseseiners, based on the number of sea lions observed from the bridge on the surface, does not reflect the level at which the actual population of sea lions is involved in this interaction, but only the presence of a certain number of sea lions interacting with commercial fishery. It is likely that only certain individuals have learnt to scavenge from the fishing vessels, and the effect of this interaction on the entire population remains unknown until an independent measure permits us to establish what fraction of the population is involved with this the jack mackerel commercial fishery.

However, the results obtained using this approach allowed us to analyse the interaction, from a spatial perspective. In addition, it was possible to identify areas where this interaction intensified, or where more sea lions have learnt to scavenge from purse-seiners, probably associated to the fishing effort in the surrounding areas.

During the descriptive analysis, differences were observed among windows regarding the number of sea lions and catches, both increasing towards the south of the study area. The number of purse-seiners, however, did not manifest any clear spatial pattern. The results enable us to propose the occurrence of 3 different types of moving windows for the study variables: (1) windows in a coastal range (Moving Windows 3, 6, 8, 9, 10 and 11), where the highest mean number of sea lions was recorded with no relation to either catches or the number of purse-seiners; (2) win- 
dows in an intermediate range (Moving Windows 2, 4, 5 and 7), with a midway mean number of sea lions, significantly related with catches; and (3) Moving Window 1, located at the farthest distance from the haulouts, with the lowest mean number of sea lions and significantly related to the number of purse-seiners. For Type (1) windows, sea lions are not related with stimuli such as catches or number of purse-seiners, both of which could be thought of as food availability stimuli for the sea lions. On the other hand, sea lions reach Type (2) windows in relation with the catches for this area, and only a scarce number of sea lions reach Type (3) windows, associated with the stimuli represented by the number of purse-seiners operating at such long distances from the coast, which sea lions presumably follow.

The feeding patterns of sea lions and seals reflect the availability and distribution of their prey (Boyd \& Croxall 1992). The jack mackerel fishing operations represent an accessible and abundant source of prey for southern sea lions (Hückstädt \& Antezana 2003). Hence, it can be proposed that if the sea lion has indeed acquired the modality of feeding from the fishing vessels instead of the typical searching and pursuing behaviour (Shaughnessy et al. 1981), then there should be a spatial co-occurrence between the sea lions and the catches and position of the jack mackerel fishing fleet, considering that the distribution of some marine mammals is tightly related to biological (such as food sources) and physical factors (Karschner et al. 2001).

In general, sea lion abundance patterns and catches are similar spatially, with a correspondence between both variables: decreasing toward the NW, while increasing toward the SE quadrant of the study area. For both nuclei with high abundances of sea lions (coastal and oceanic), the closest haul-out corresponded to Isla Mocha, a reproductive colony with an estimated population of 1100 individuals (Aguayo-Lobo et al. 1998). Furthermore, these centres are spatially overlapped with nuclei where high catches were recorded, and thus, these can be proposed as hot-spots of the interaction between sea lions and purse-seiners, since the number of sea lions can be considered as indicative of the intensity of the interaction.

The bathymetry of the area under study is characterised by the presence of a very shallow and narrow continental shelf (less than $200 \mathrm{~m}$ in depth and about $36 \mathrm{n}$ miles in width), followed by very a steep continental slope (less than $50 \mathrm{n}$ miles) and then reaching the sea bed with depths over $4500 \mathrm{~m}$. The coastal hotspot was located above the continental slope, where the depths are about $2500 \mathrm{~m}$, whereas the oceanic hotspot is located over a rising of the ocean bottom, at a depth of $4000 \mathrm{~m}$.
No clear relationship was found between the number of sea lions and the number of purse-seiners, with the exception of the oceanic hot-spot, where a low abundance of purse-seiners was recorded, and another centre, where the inverse relationship was found (low abundance of sea lions, high abundance of purseseiners). This centre was also recorded as a low catch centre, and the same pattern between catches and number of purse-seiners was also recorded at the coast (ca. $39^{\circ} \mathrm{S}$ ) and north of Isla Mocha.

Thus, it is possible to propose a defined sector where the interaction between southern sea lions and the jack mackerel purse-seiner fleet gains a greater importance, located between 38 and $40^{\circ} \mathrm{S}$ and between $75^{\circ} 30^{\prime} \mathrm{W}$ and the coastline. Karschner et al. (2001) propose that the hot-spots overlapping between marine mammal feeding grounds and fisheries in the North Atlantic correspond to the most productive fishing zones, but also areas from which most reports of fishing-mammals interactions originate. In this study, the location of hot-spots co-occur with those areas of greatest fishing yield for the jack mackerel commercial fishery, here represented as catches, and therefore, the areas where the interaction with the sea lions is more intense.

As mentioned above, it remains unknown what fraction of the population is engaged in this interaction with the jack mackerel fishing fleet off central Chile. However, the results obtained from the present study indicated that the largest catches and number of sea lions are concentrated in the area surrounding Isla Mocha's colony.

Although the historical development of commercial fishery in the area is not well known, during 2002, purse-seiner fleets were focused preferentially in this zone (L. A. Hückstädt unpubl. data), and presumably the animals that interacted with the vessels came from the colony of Isla Mocha.

It has been proposed that the animals engaged in this interaction actually approach the fishing vessels, acquiring then their food directly from the fish caught in the net (L. A. Hückstädt \& T. Antezana 2003, unpubl. data). In general, the fishing fleet probably concentrates its effort around this area because of the high biomass of jack mackerel found, and the presence of sea lions around the purse-seiners is explained not by the availability of free prey, but by the stimuli implied by the presence of the fishing vessels and, possibly, the noise of their engines (Hückstädt \& Antezana 2003).

The above statement could be reinforced if it is considered that, on those occasions when observations were conducted in the surroundings of Cobquecura colony (the largest colony of sea lions in the area), only a scarce number of sea lions were observed in associa- 
tion with the low number of purse-seiners operating (and hence a less intense stimuli for the sea lions to approach). In addition, the fishing fleet does not operate in this area very often, which could imply that only a few sea lions from this colony are accustomed to obtaining their food directly form the jack mackerel fishing fleet. Hückstädt \& Antezana (2003) propose that sea lion density at fishing grounds may be associated with a learned knowledge of the productivity of the fishing grounds instead of the distance to the haulouts, which is reinforced by the results of this work.

Acknowledgements. We would like to express our gratitude to B. Yanniccelli, G. Hoffman, R. Quiñones and T. Antezana, for their collaboration during this study. We also acknowledge Cía. Pesquera Itata S.A. and E. Cisternas for their logistical support; as well as C. Beans, who corrected the English of this manuscript. We thank 3 anonymous reviewers whose suggestions greatly contributed to improving our manuscript. This research was funded under Grants in aid of Research (Society for Marine Mammalogy) and Beca Jorge Tomicic Karzulovic (Sociedad Chilena de Ciencias del Mar and Minera Escondida Ltda.). During the writing of this manuscript, L.A.H. spent an internship at Geovetarcentrum, Göteborg Universitet, Sweden, supported by SIDA, through Project Linnaeus, Palme 2002. L.A.H.'s graduate studies were supported by Escuela de Graduados (Universidad de Concepción).

\section{LITERATURE CITED}

Aguayo A, Maturana R (1973) Presencia del lobo marino común (Otaria flavescens) en el litoral chileno. Biol Pesq (Chile) 6:45-75

Aguayo-Lobo A, Díaz H, Yáñez J, Palma F, Sepúlveda M (1998) Censo poblacional del lobo marino común en el litoral de la V a IX Regiones. Informe Técnico Fondo de Investigación Pesquera (Chile) FIP-IT/96-51

Beverton RJH (1985) Analysis of marine mammal-fisheries interaction. In: Beddington JR, Beverton RJH, Lavigne DM (eds) Marine mammals and fisheries. George Allen \& Unwin, London, p 3-33

Bjørge A, Øien N, Hartvedt S, Bøthun G, Bekkby T (2002) Dispersal and bycatch mortality in gray, Halichoerus grypus, and harbor, Phoca vitulina, seals tagged at the Norwegian coast. Mar Mamm Sci 18:963-976

Boyd IL, Croxall JP (1992) Diving behaviour of lactating Antarctic fur seals. Can J Zool 70:919-928

Campagna C, Werner R, Karesh W, Marin MR, Koontz F, Cook R, Koontz C (2001) Movements and lactation at sea of South American sea lions (Otaria flavescens). J Zool (Lond) 257:205-220

Castro LR, Quiñones R, Arancibia H, Figueroa D, Roa R, Sobarzo M, Retamal M (1997) Áreas de desove de anchoveta y sardina común en la zona central. Informe Final Proyecto Fondo de Investigación Pesquera (Chile) 1996-11

Cressie NA (1993) Statistics for spatial data. John Wiley \& Sons, New York

Cubillos L, Núñez S, Véjar F, Torres P and 14 others (2003) Evaluación del stock desovante de anchoveta y sardina común entre la V y X Regiones, año 2002. Informe Técnico Fondo de Investigación Pesquera (Chile) FIP-IT/2002-14
Englund EJ, Sparks A (1988) GEO-EAS (Geostatistical Environmental Assessment Software) user guide. US Environmental Protection Agency, Las Vegas, NV

FAO (1977) Mammals in the seas, Vol 1. Report of the FAO Advisory Committee on Marine Mammals. Working Party on Marine Mammals. FAO, Rome

George-Nascimento M, Bustamante A, Oyarzún C (1985) Feeding ecology of the South American sea lion Otaria flavescens: food contents and food selectivity. Mar Ecol Prog Ser 21:135-143

Goovaerts P (1997) Geostatistics for natural resources evaluation, 2nd edn. Oxford University Press, New York

Grechina A (1998) Historia de investigaciones y aspectos básicos de la ecología del jurel Trachurus symmetricus murphyi (Nichols) en alta mar del Pacífico Sur. In: Arcos D (ed) Biología y ecología del jurel en aguas chilenas. Instituto de Investigación Pesquera, Talcahuano, p 11-34

Hückstädt LA, Antezana T (2003) Behaviour of the southern sea lion (Otaria flavescens) and consumption of the catch during purse-seining for jack mackerel (Trachurus symmetricus) off central Chile. ICES J Mar Sci 60:1003-1011

Isaaks EH, Srivastava RM (1989) Applied geostatistics. Oxford University Press, New York

Jennings S, Kaiser MJ (1998) The effects of fishing on marine ecosystems. Adv Mar Biol 34:201-352

Kaschner K, Watson R, Christensen V, Trites AW, Pauly D (2001) Modelling and mapping trophic overlap between marine mammals and commercial fisheries in the North Atlantic. In: Zeller D, Watson R, Pauly D (eds) Fisheries impacts on North Atlantic ecosystems: catch, effort and national/regional datasets. Fisheries Centre Research Report 9(3), Fisheries Centre, Vancouver, p 35-45

Loughlin TR, Ingraham WJ Jr, Baba N, Robson BW (1999) Use of a surface-current model and satellite telemetry to assess marine mammal movements in the Bering Sea. In: Loughlin TR, Ohtani K (eds) Dynamics of the Bering Sea. University of Alaska Sea Grant, Fairbanks, AK, p 615-629

Northridge SP (1984) World review of interactions between marine mammals and fisheries. FAO Fisheries Paper Collection No. 251. FAO, Rome

Oliva J, Montenegro C, Braun M, Rojas O and 11 others (2001) Evaluación del stock desovante de anchoveta en la I y II regiones año 2000. Informe Final Proyecto Fondo de Investigación Pesquera (Chile) 2000-06

Oliva J, Montenegro C, Braun M, Rojas O and 11 others (2002) Evaluación del stock desovante de anchoveta por el método de producción de huevos en la I y II Regiones, año 2001. Informe Final Proyecto Fondo de Investigación Pesquera (Chile) 2001-10

Oporto JA, Brieva LM, Navarro R, Turner A (1999) Cuantificación poblacional de lobos marinos en la X y XI Regiones. Informe Final Proyecto Fondo de Investigación Pesquera (Chile) 1997-44

Petitgas P (1993) Geostatistics for fish stock assessments: a review and an acoustic application. ICES J Mar Sci 50: 285-298

Petitgas P (1996) Geostatistics and their applications in fisheries survey data. In: Megrey BA, Moksness E (eds) Computers in fisheries research. Chapman \& Hall, London, p 113-142

Petitgas P (2001) Geostatistics in fisheries survey design and stock assessment: models, variances and applications. Fish Fish 2:231-249

Rivera A (1990) Etología: displays agonísticos presentes en Otaria flavescens (Shaw, 1800), Punta Hualpén, Chile (Mammalia: Otariidae). Gayana Zool 54:33-49

Roa R, Tapia F (2000) Cohorts in space: geostatistical map- 
ping of the age structure of the squat lobster (Pleuroncodes monodon) population off Central Chile. Mar Ecol Prog Ser 196:239-251

Rossi RE, Mulla DJ, Journel AG, Franz EH (1992) Geostatistical tools for modelling and interpreting ecological spatial dependence. Ecol Monogr 62:277-314

Rueda M (2001) Spatial distribution of fish species in a tropical estuarine lagoon: a geostatistical appraisal. Mar Ecol Prog Ser 222:217-226

Sepúlveda M (1998) Circaritmos de actividad del lobo marino común Otaria flavescens (Carnivora: Otariidae) y su relación con la salmonicultura en la Décima Región, Chile. Bs Mar Biol thesis, Instituto de Oceanología, Universidad de Valparaíso, Chile

SERNAPESCA (Servicio Nacional de Pesca) (2002) Anuario Estadístico de Pesca 2001. Ministerio de Economía, Fomento y Reconstrucción, Valparaíso

Shaughnessy PD (1985) Interactions between fisheries and Cape fur seals in southern Africa. In: Beddington JR, Beverton RJH, Lavigne DM (eds) Marine mammals and fisheries. George Allen \& Unwin, London, p 119-134

Shaughnessy PD, Semmelink A, Cooper J, Frost PGH (1981) Attempts to develop acoustic methods of keeping Cape fur seals Arctocephalus pusillus from fishing nets. Biol Conserv 21:141-158

Shima M, Hollowed AB, VanBlaricom GR (2000) Response of pinniped populations to direct harvest, climate variability, and commercial fishery activity: a comparative analysis. Rev Fish Sci 8:89-124

Sielfeld W, Guerra C, Durán LR, Acuña E (1997) Monitoreo de

Editorial responsibility: Otto Kinne (Editor),

Oldendorf/Luhe, Germany la pesquería y censo del lobo marino común en el litoral de la I-IV Regiones. Informe Final Proyecto Fondo de Investigación Pesquera (Chile) 1995-28

Sobarzo M, Figueroa D, Djurfeldt L (2001) Upwelling of subsurface water into the rim of the Biobío submarine canyon as a response to surface winds. Cont Shelf Res 21:279-299

SUBPESCA (Subsecretaría de Pesca, Chilean Fisheries Secretary) (2000) Cuota global de captura para la pesquería del recurso jurel, año 2001. Informe Técnico (R Pesq) No. 70

Thompson D, Duck CD, McConnell BJ, Garrett J (1998) Foraging behaviour and diet of lactating female southern sea lions (Otaria flavescens) in the Falkland Islands. J Zool (Lond) 246:135-146

Torres DN (1979) Mamíferos marinos de Chile: antecedentes y situación actual. Biol Pesq (Chile) 11:49-81

Vaz-Ferreira R (1979) South American sea lion. In: Report of the FAO Advisory Committee on Marine Resources Research, Working Party in Marine (eds) Mammals in the seas, Vol 2: Pinniped species and report on sirenians. FAO, Rome, p 9-12

Webster R, Oliver MA (2001) Geostatistics for environmental scientists. John Wiley \& Sons, West Sussex

Werner R, Campagna C (1995) Diving behaviour of lactating southern sea lions (Otaria flavescens) in Patagonia. Can J Zool 73:1975-1982

Wickens PA (1995) A review of operational interactions between pinnipeds and fisheries. FAO Fish Tech Rep 346

Wickens PA, Japp DW, Shelton PA, Kriel F (1992) Seals and fisheries in South Africa - competition and conflict. S Afr J Mar Sci 12:773-789

Submitted: October 23, 2003; Accepted: July 27, 2004

Proofs received from author(s): November 5, 2004 